\title{
REDUCTION OF WORK IN PROCESS INVENTORY AND PRODUCTION LEAD TIME IN A BEARING INDUSTRY USING VALUE STREAM MAPPING TOOL
}

\author{
Praveen Saraswat $^{1}$, Deepak Kumar ${ }^{2}$ and Manoj Kumar Sain ${ }^{3}$ \\ ${ }^{1}$ Senior Lecturer, ${ }^{2,3}$ Associate Professor \\ ${ }^{1,3}$ Swami Keshvanand Institute of Technology, Jaipur \\ ${ }^{2}$ Poornima College of Engineering, Jaipur
}

\begin{abstract}
Manufacturers always face cost-reduction and efficiency challenges in their operations. Industries require improvement in Production Lead Times, costs and customer service levels to survive. Because of this, companies have become more customers focused. The result is that companies have been putting in significant effort to improve their efficiency.

In this paper Value Stream Mapping (VSM) tool is used in bearing manufacturing industry by focusing both on processes and their cycle times for a product UC- 208 INNER which is used in plumber block. In order to use the value stream mapping, relevant data has been collected and analyzed. After collecting the data customer need was identified. Current state map was draw by defining the resources and activities needed to manufacture, deliver the product. The study of current state map shows the areas for improvement and identifying the different types of wastes. From the current state map, it was noticeable that Annealing and CNC Machining processing have higher cycle time and work in process.
\end{abstract}

The lean principles and techniques implemented or suggested and future state map was created and the total lead time was reduced from 7.3 days to 3.8 days. The WIP at each work station has also been reduced. The production lead time was reduced from 409 seconds to 344 seconds.

\section{KEYWORDS}

Lean Principles, Value Stream Mapping, Wastes, Work in Process, Production Lead Time

\section{INTRODUCTION}

Industries upset more capital and resources to improve their productivity. It is necessary to optimize their capital, time and working environment. Industries needed improvements tools to optimize its processes to attain more capable results. Many improvement techniques and tools were developed and adapted to work in the different types of business.

Now day's industries focused on more production with higher efficiency in less lead time. The companies focused mainly on customer satisfaction. In an increasingly competitive environment, 
many manufacturing firms are looking for a winning card over their competition. Manufacturers have to understand that the conventional production system has to connect with the lean tools and techniques. Lean manufacturing system was developed by Toyota, Japan.

\section{VALUE STREAM MAPPING}

Value Stream Mapping (VSM) tool shows all the activities, from supply to final product through the different processing steps.. In other words it is a sketch of a production line [1].

Value stream map is the techniques that bring the all processing steps at one place. It shows the big picture of shop floor rather than individual processes and improving the each area at the production line. It is used to draw attention to different wastes and eliminating them in future state map.

It is necessary that every process as closely as possible produces only what its customers need when they need it. The existing processes have some types the waste in a production line which is the result of product design and machinery

\section{LITERATURE REVIEW}

Value Stream Mapping (VSM) is used to define and analyze the current state for a product value stream and design a future state focused on reducing waste, improving lead-time, and improving workflow [2].A value stream map provides a blueprint for implementing lean manufacturing concepts by illustrating how the flow of information and materials should operate [3]. VSM is divided into two components: big picture mapping and detailed mapping [4]. Rajenthirakumar and R.G. Shankar reported a noticeable reduction in cycle time and increase in cycle efficiency with an application of value stream mapping (VSM). The production flow was optimized thus minimizing several non-value added activities/times such as bottleneck time, waiting time, material handling time, etc. [5]. K. P. Paranitharan provide useful platform for research in implementation of lean tools in any manufacturing unit. Their results show a significant improvement in productivity, reduction of Production Lead Time and reduction in inventory. These can be achieved by creating flow by layout modification and balance to TAKT time [6].R.M. Belokar reported a case study of application of VSM in an automobile industry where they achieved nearly $67 \%$ improvement in cycle time by improvement in value adding activities [7]. The conclusion of literature review is shown in below table. 
International Journal of Managing Value and Supply Chains (IJMVSC) Vol. 6, No. 2, June 2015

Table 1 Inventory and Lead time of different industries

\begin{tabular}{|c|c|c|c|c|c|c|c|}
\hline \multirow{2}{*}{$\begin{array}{l}\text { Name of } \\
\text { Industry }\end{array}$} & \multicolumn{3}{|c|}{ Inventory (units) } & \multicolumn{3}{|c|}{ Lead Time } & \multirow{2}{*}{$\begin{array}{l}\text { References } \\
\text { No. }\end{array}$} \\
\hline & Current & Future & $\%$ Reduction & Current & Future & $\%$ Reduction & \\
\hline $\begin{array}{l}\text { Chinese } \\
\text { Industry }\end{array}$ & 327,000 & 65,000 & 80.12 & 67 days & 16 days & 76.12 & 9 \\
\hline $\begin{array}{l}\text { Construction } \\
\text { Equipment } \\
\text { Company }\end{array}$ & & & & $\begin{array}{l}1300 \\
\text { mins }\end{array}$ & $\begin{array}{l}800 \\
\text { mins }\end{array}$ & 38.46 & 8 \\
\hline $\begin{array}{l}\text { Automotive } \\
\text { Component } \\
\text { Manufacturing } \\
\text { Industry }\end{array}$ & 2200 & 200 & 90.91 & & & & 10 \\
\hline $\begin{array}{l}\text { Automotive } \\
\text { Assembly Line }\end{array}$ & 5 & 2 & 60.00 & $82 \mathrm{hrs}$ & $29 \mathrm{hrs}$ & 64.63 & 6 \\
\hline $\begin{array}{l}\text { Gearbox } \\
\text { manufacturing } \\
\text { Industry }\end{array}$ & & & & $\begin{array}{l}33.16 \\
\text { days }\end{array}$ & $\begin{array}{l}14.68 \\
\text { days }\end{array}$ & 55.73 & 11 \\
\hline
\end{tabular}

\section{RESEARCH METHODOLOGY}

The research objective is to reduce the production lead time and WIP in order to increase the production rate in TEI Company, Jaipur so that customer order demand can be fulfill. Batch processing in full capacity and bottlenecks in the production process are key contributors to long Production Lead Times. The results of the research would have direct impact on product Production Lead Time and WIP which would aid in reducing cost and meeting customer demand.

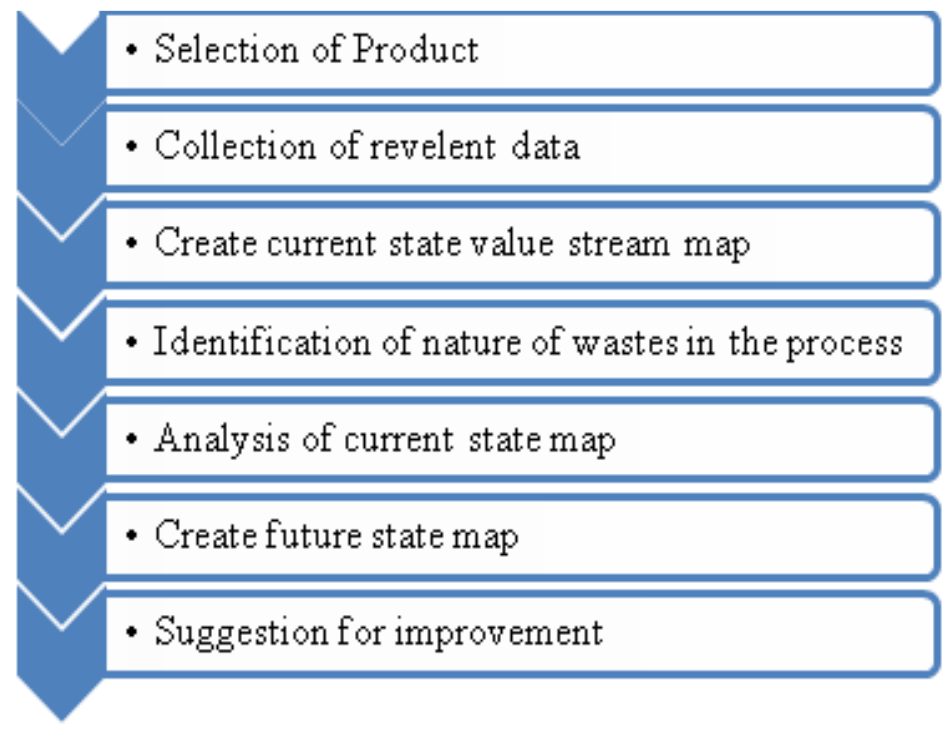

Figure-1 Methodology Steps for Implementing Value Stream Mapping

The following strategies were applied for achieving the methodology steps:

- Detail of product, processes and other information obtained from company.

- Time studies for finding the time duration \& data collected from shop floor observation.

- For drawing current and future state value map E draw software was used. 
The current information was collected directly from the company by talks and discussions with managers, owner, and production supervisors. Example of such information is customer demand, general process flow, supply of raw material etc. Time studies were conducted to get exact information regarding cycle time, changeover time within each processing steps. The time studies gave the observed value of time for individual processes.

Information about cycle time, changeover time, and number of operators involved in each processing steps, amount of inventory and work-in progress between processes was determined. Current map was drawn which shows the material and information flow. Takt time was calculated and compared to average cycle time. The different areas were identified which needed improvement. Thereafter, future state map was developed followed by some suggestions. Lean tools and techniques were suggested for improvising the material and information flow.

\section{PREPARATION OF CURRENT STATE VALUE STREAM MAP}

Current state VSM is used to map work processes, material flow, and information flow. For this project Edraw software is used to create current state and future state VSMs. E-Draw Max is a vector-based diagramming application with rich examples and templates. Easy to create flow charts, organizational charts, busi-ness process, UML diagrams, work flows, program structures, net-work diagrams, chart and graphics, mind map, directional maps and database diagrams.

Table 2 Value Stream map input data

\begin{tabular}{|c|c|}
\hline Customer Order & 5000 (one week) \\
\hline Working Hours & Two shift with 12 hours per day \\
\hline Break & One hour/shift \\
\hline Raw Material & Weekly \\
\hline Working Day/ Week & 6 days \\
\hline
\end{tabular}




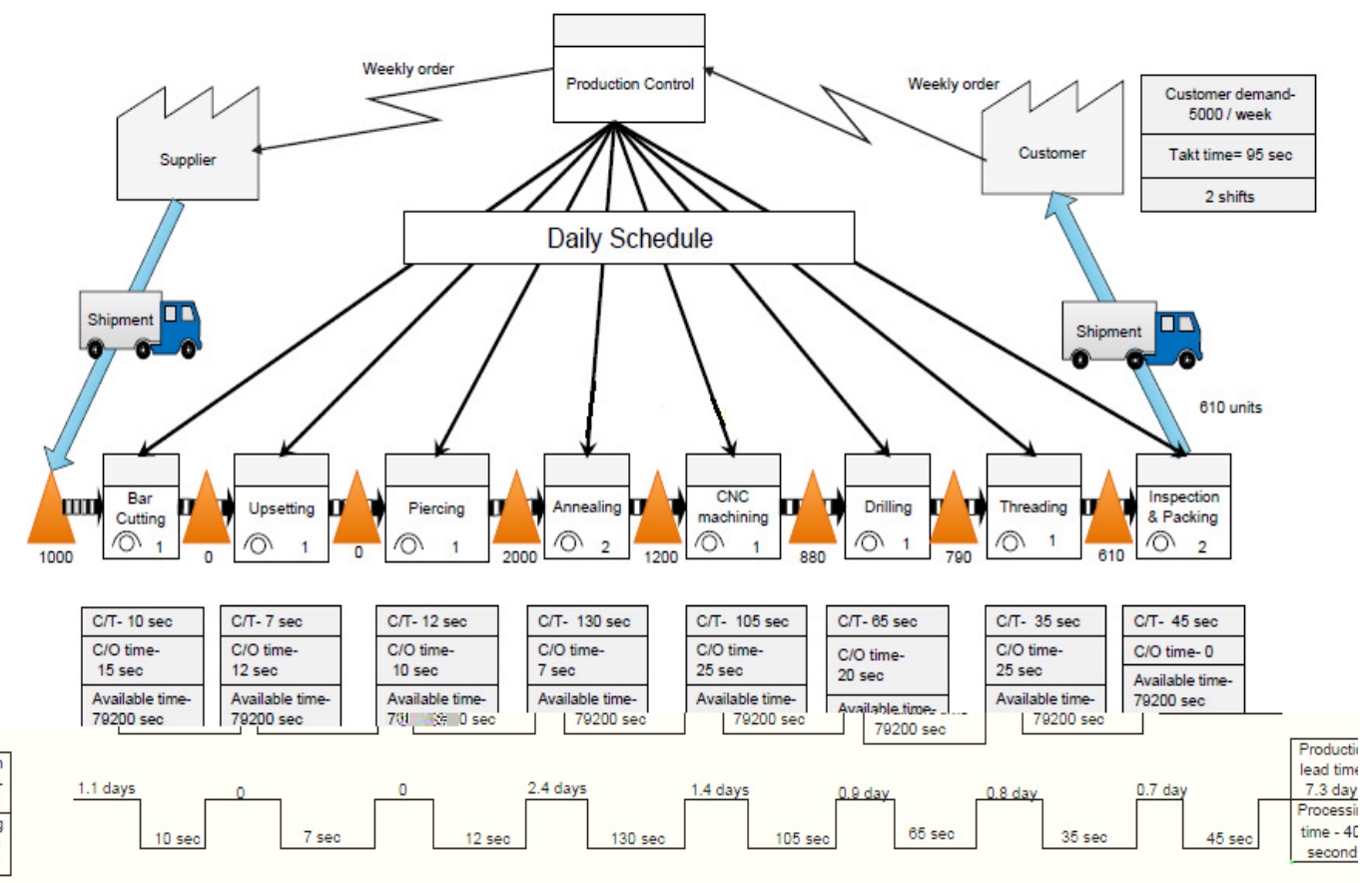

Figure- 2 Current state value stream map

\section{ANALYSIS OF CURRENT STATE MAP}

(a)Identification of non value adding activities

The actual value added time is 400 seconds and the lead time is 7.3 days so it is clear that the ratio of value added time to lead time is vey less.

There is a transportation waste from CNC machining to Drilling process, it takes 3 minutes. CNC machining is done on ground floor while drilling \& threading is done on first floor which leads to increase the unnecessary time between the processes.

The furnace is a bottleneck for the CNC machining process. The capacity of the furnace is low due to which there is WIP worth of 1.3 days accumulates before it. The other reason for high accumulation of inventory is the method of production in large batch sizes.

(b) TAKT time calculation

Weekly demand $=5000$ units

Available working day in a week $=6$ days

Demand per day $=\frac{5000}{6}=833$ units

$$
\text { TAKT Time }=\frac{\text { Net available time per day }}{\text { Customer demand per day }}
$$


International Journal of Managing Value and Supply Chains (IJMVSC) Vol. 6, No. 2, June 2015

$$
=\frac{79200}{833}=95 \text { seconds }
$$

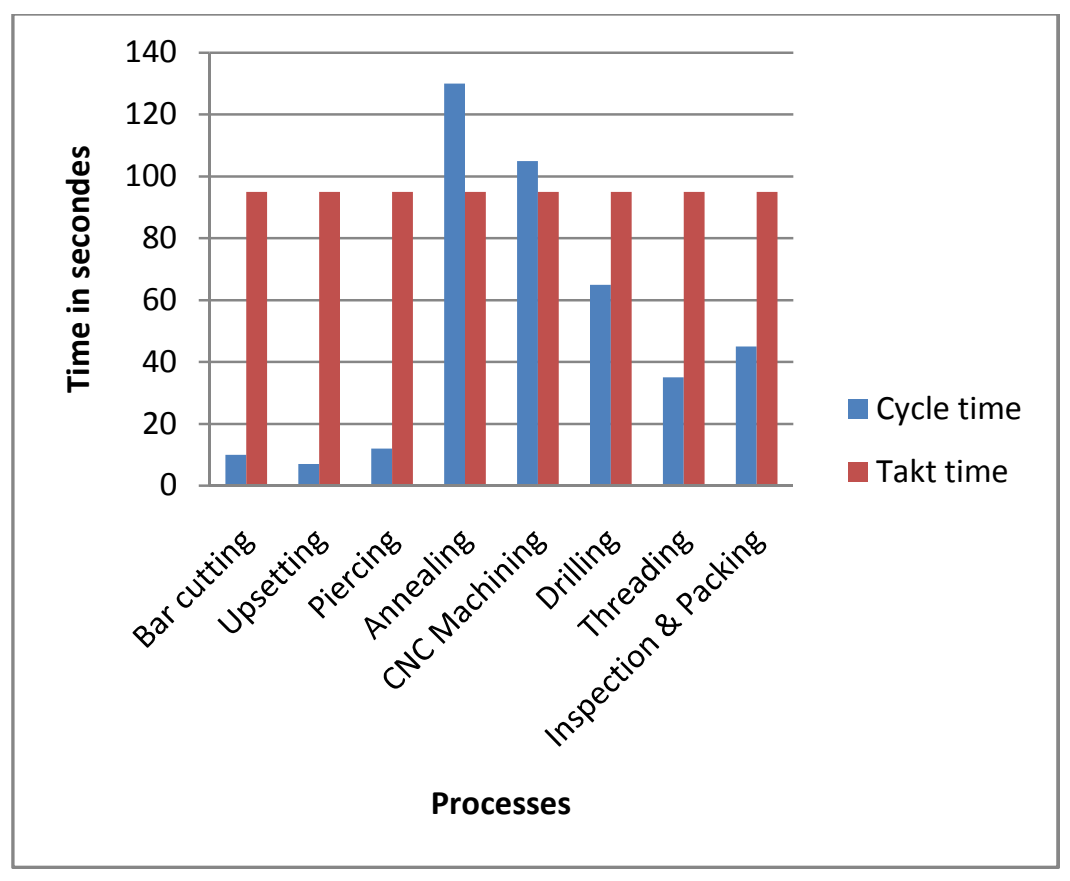

Figure- 3 Comparison between Cycle time and Takt time

\section{FUTURE STATE MAP}

The future state map is draw to give propose suggestions and recommendations for improvement in the current position of the company. 


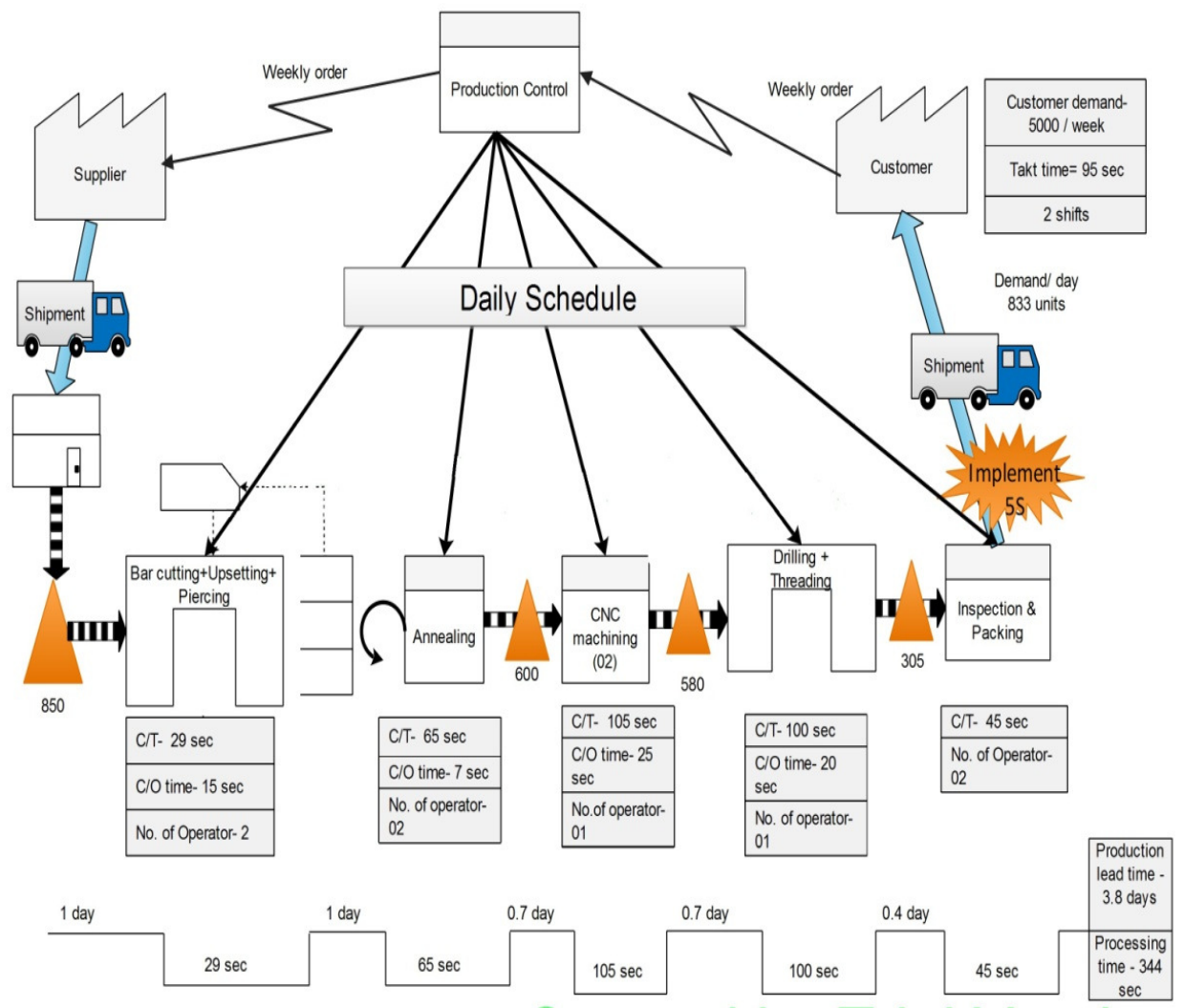

Figure- 4 Future state map

In future state map the total work station is 5.Supermarket is used for storage of WIP in future for storage of WIP, this reduces the excessive WIP at annealing. Production kanban is also used which give the storage information to the work cell (Bar cutting, Upsetting, Piercing) for maintaining the production. A warehouse is introduced in the future map for storage of raw material. Whenever there is requirement, raw material is available so inventory reduced at first work station. The capacity of annealing furnace will be increased to double so cycle times reduce to half. At CNC machining work station it is proposed to have one more CNC machine. The WIP at $\mathrm{CNC}$ machining reduced. After that there is another work cell which combines Drilling and threading process. The no of operator will reduce at this work cell. At last work station the no of operator increased to two which reduce the WIP at Inspection \& Packing.

\section{RESULTS \& SUGGESTIONS}

Comparative study show the significant reduction occurs in WIP and Production Lead Time. Value stream mapping technique was used to draw maps and after applying some tools and giving somesuggestions for the product. 
International Journal of Managing Value and Supply Chains (IJMVSC) Vol. 6, No. 2, June 2015

Table- 3 Reduction in work in process of different processes

\begin{tabular}{|l|c|c|c|}
\hline \multicolumn{1}{|c|}{ Processes } & $\begin{array}{c}\text { WIP in } \\
\text { Current map }\end{array}$ & $\begin{array}{c}\text { WIP in } \\
\text { Future map }\end{array}$ & $\begin{array}{c}\% \\
\text { Reduction }\end{array}$ \\
\hline Annealing & 2000 & 610 & $69.7 \%$ \\
\hline CNC Machining & 1200 & 600 & $50 \%$ \\
\hline $\begin{array}{l}\text { Drilling \& } \\
\text { Threading }\end{array}$ & 1790 & 580 & $67.6 \%$ \\
\hline $\begin{array}{l}\text { Inspection \& } \\
\text { Packing }\end{array}$ & 880 & 305 & $65.4 \%$ \\
\hline
\end{tabular}

Table- 4 Reduction in production lead time

\begin{tabular}{|c|c|c|c|}
\hline Time & $\begin{array}{l}\text { Current state } \\
\text { map }\end{array}$ & $\begin{array}{l}\text { Future state } \\
\text { map }\end{array}$ & \% reduction \\
\hline Production Lead Time & 7.3 days & 3.8 days & $48 \%$ \\
\hline Total Processing Time & 409 seconds & 344 seconds & $15.9 \%$ \\
\hline
\end{tabular}

Value stream mapping analysis at TEI gives the areas which have different types of wastes and require a lot of improvement. So following suggestions are advised to TEI regarding the shop floor activities improvement.

I. As shown in current state map there was no proper place for the storage. A warehouse can be there for storage purpose. It improves the handling of raw material.

II. As shown in current state map the drilling and threading operation carried out on first floor which results in unnecessary motion. So it is advised to TEI that these operations can continue with $\mathrm{CNC}$ machining on ground floor.

III. For easy flow of work in process inventory supermarket can be used in between the processes. It results in pull system in the production line.

IV. There was no free space for finished product or shipping product at the end. Management suggested that $5 \mathrm{~S}$ lean technique can be used to improve the working environment.

V. It is necessary that cycle time should be near about takt time. It can be achieved by balancing the production line.

\section{CONCLUSION}

This research study describes how the value mapping can be used to visualize graphically the flow of material and flow of information from customer order to finish product. With this approach (VSM) wastes in the company can be reduced.

The measure of success of value stream mapping in this research was address on how one could reduce the wastes identified through the value stream mapping. The results indicate that TEI should be incorporate production kanban, pull system and supermarket wherever possible according to the customer satisfaction. 
It can be concluded that VSM study has been able to highlight a number of unnecessary activities in the process of manufacturing of bearing components. These activities have been connected to waste such as WIP, storage and longer Production lead time etc.

\section{REFERENCES}

[1] J. P. Womack, D. T. Jones, and D. Ross, The machine that changed the world. New York: Harper Collins Publishers, 1991.

[2] M. Rother and J. Shook, Learning to see: Value stream mapping to add value and eliminate muda, 2nd ed. Brookline, MA: The Lean Enterprise Institute Inc, 1999.

[3] M. Rother and J. Shook, Learning to See: Value Stream Mapping to create value and eliminate muda. Brrokline, USA: The Lean Enterprise Institute, 1999.

[4] Hines P, Taylor D. Going lean. Cardiff, UK: Lean Enterprise Research Centre Cardiff Business School, 2000.

[5] D. Rajendrakumar and R. Gowtham Shankar, "Analyzing the Benefits of Lean Tools: A Consumar Durables Manufacturing Company Case study," International Journal of Engineering, 2011.

[6] K. P. Paranitharan, "Redesinging an Automotive Assembly Line Through Lean Strategy," International Journal of Lean thinking, 2011.

[7] R.M. Belokar and Vikas Kumar, " An Application of Value Stream Mapping In Automotive Industry: A Case Study," International Journal of Innovative Technology and Exploring Engineering, 2012.

[8] D. Rajenthirakumar \& S.G. Harikarthik, "Process Cycle Efficiency Improvement through Lean: A Case Study," International Journal of Lean Thinking, 2011.

[9] Meng B, D. Mingyao, Research on the Lean Process Reengineering Based on Value Stream Mapping. Management Science and Engineering, Vol. 6, No. 2, 2012, pp. 103-106, 2012.

[10] D. Rajenthirakumar,P.R. Thyla, Transformation to Lean Manufacturing By an Automative Component Manufacturing Company. International Journal of Lean Thinking Volume 2, Issue 2, 2011.

[11] D. Rajenthirakumar, P. R. Thyla \& John Paul Ajay, Implementation of Lean Assembly Line: A Case Study, International Journal of Engineering, tome VIII, Fascicule 3, 2010.

[12] Singh, B., and Sharma, S. K. , "Value stream mapping as a versatile tool for lean implementation: an Indian case study of a manufacturing firm", Measuring Business Excellence, Vol. 13, No. 3, pp. 5868,2009 .

[13] Brunt, D. From current state to future state: Mapping the steel to component supply chain. International Journal of Logistics: Research and Applications, 3, (3), 259-271, 2000.

[14] Ritesh R. Bhat and Prof. S. Shivakumar, "Improving the Productivity using Value Stream Mapping and Kanban Approach", International Journal of Scientific \& Engineering Research Volume 2, Issue 8, August-2011. 